\title{
$\mathbb{N}$ \\ NORDIC JOURNAL \\ of Science and Technology Studies \\ INTRODUCTION: ENGAGING ENVIRONMENTS
}

\author{
by Ann-Sofie Kall and Hilde Reinertsen
}

What are the relations between social movements, public engagement, and democracy within the field of the environment, broadly defined? How have people engaged with nature in different ways, at different sites and during different times? And how have these multiple engagements with nature and the environment (including the climate) also been matters of politics? This special issue will not provide definitive answers to these broad questions, but as we will show in this introduction, they have guided the empirical investigations and theoretical reflections that the articles in combination bring to the table. The title of the issue - 'Engaging Environments' - seeks to capture precisely this point: That nature and politics, the environment and public engagement, are always intertwined. Yet how, more precisely?

The questions and assertions posed above have been of longstanding concern and interest within Science and Technology Studies (STS). One strand of STS, the field of Public Engagement with Science (PES), emerged in part from investigations into environmental controversies where lay people, experts, and governments came into conflict. Wynne's analysis of the struggle over the existence of pollution from the Sellafield nuclear facility in England and over whether this plant caused the illness of grazing sheep in its vicinity has become a standard reference in the study of public engagement (Wynne 1992). Having been published in the opening edition of the journal Public Understanding of Science, this piece took part in defining a new field of STS inquiry. While 'public understanding' is still in the journal's name, the field at large has shifted its preferred concept to 'public engagement', signifying the field's core argument of not seeing the science-society relation as a one-way route with publics simply receiving science's solutions, but rather as a mutual relation in which publics partake in the very defining and framing of science and technology.

Much of the literature on public engagement has sprung out of sociological investigations of the environment, environmental politics, and environmental engagement (Irwin 1995, 2001, Leach et al. 2005, Lidskog \& Sundqvist 2011, Soneryd and Weldon 2003). Within this field, some strands have been interested in public engagement broadly defined, investigating how lay people, ad hoc groups, and local activists have gathered around specific issues (Latour 2004, Marres 2007). Others have investigated environmental organizations (commonly referred to as ENGOs, environmental nongovernmental organizations) with special concern for how these are organized and what signifies them vís-a-vís other social movements. Having studied environmental organizations in the UK, Yearley suggests three characteristic features of the environmental movement: "its intimate relation to science, its practical claims to international solidarity and its ability to offer a critique of, and an alternative to, capitalist industrialism" (Yearley 2005:25). Although qualifying his claim by pointing to exceptions and contradictions, he maintains that a theory of environmental movements must be empirically founded; hence, he calls for an empirical universalism, in which the sociological theory is founded upon detailed and broad empirical investigations.

These discussions within PES and STS at large have framed both this special issue and the different processes leading up to its publication, yet a specific empirical object has also been at the center of our attention throughout the process: Norway's oldest environmental organization, the Norwegian Society for the Conservation of Nature (SCN), which celebrated its centennial in 2014. As part of its anniversary preparations, SCN commissioned a short publication about its history which was to highlight key events, topics, and issues of interest to scholars and activists alike (Reinertsen and Asdal 2010). In doing this work, Reinertsen and Asdal pursued a dual interest in investigating the empirical object of SCN's rich history, which is important in and of itself, while also placing SCN within the wider context of environmental engagement and STS at large.

Given its long history, the Norwegian Society for the Conservation of Nature has experienced multiple shifts in both its organization, body of members, working methods, and issues of concern. The organization was founded on February 18, 1914, by a group of academics in the major Norwegian cities, notably professors of Botany, Natural History, and Law at the universities in Oslo, Bergen, and Trondheim. Similar organizations had been established in Sweden in 1909 and Denmark in 1911 (Anshelm 2004, Berntsen 2014, Naturskyddsföreningen 2009, Olsen 2015, Trædal
Note:

Authors:

Licensing:

This article serves as an introduction to the following articles, and has not been subjected to a peer-review process.

Ann-Sofie Kall

Unit of Technology and Social Change, Linköping University E-mail: ann-sofi.kall@liu.se

\section{Hilde Reinertsen}

Centre for Technology, Innovation and Culture, University of Oslo

E-mail: hilde.reinertsen@tik.uio.no 


\section{$\$$}

NORDIC JOURNAL

of Science and Technology Studies

2013). The Norwegian organization may be considered the institutionalization of a looser interest group for conservation which in 1909 had drafted a law for the protection of Norwegian nature. A key concept in this law was nature's intrinsic value ('naturens egenverdi') which needed special protection. The law was approved and adopted by the Norwegian government almost unchanged in 1910, granting Norway its Conservation Act (Gundersen 1991, Reinertsen and Asdal 2010). Hence, a key moment of Norwegian environmental engagement (at this point in time understood as conservation of nature) was simultaneously a key moment of Norwegian democracy: A young nation, only five years out of its union with Sweden, granted not only its citizens and their property but also nature as such protection under the law.

From the start, then, nature and politics, environment and democracy, were intertwined. Soon, new questions arose: What specific parts of nature should be granted the status of conservation? What species, sites, and areas were worthy of being protected, and which were not? What should protection mean in practice? And how to sanction violations? During the ensuing decades, specific birds, animals, trees, waterfalls, and mountain terrains were granted protection, but most were surely not. In the postwar era, industrial expansion transformed numerous Norwegian valleys and waterfalls into production sites with hydroelectric power plants. The government established offices and systems of environmental regulation to handle these increasing industrial emissions, making environmental concerns into an issue of protecting the industry as much as nature (Asdal 2011a, 2011b). During these years, SCN itself changed from a small elite organization into a broader grassroots movement with members across the country, many of whom took part in demonstrations to mark their resistance against the building of hydropower plants in Norwegian valleys and fjords. Protection of waterfalls was reinvigorated as the ultimate symbol of protecting nature from human intervention, now also with the extra dimension of halting industrial pollution. In this way, SCN and its members shifted from working solely with the government and the law to also working against it, even at times breaking the law (Nilsen 2008), hence changing the methods and identity politics of the environmental engagement with it from a conservative to a radical streak (Gundersen 1991, Reinertsen and Asdal 2010).

The image of environmental engagement as anti-establishment and counter-culture stems from these defining struggles of the 1960s and 1970s. But as shown above, this has not always been the case, and is not so today. SCN has maintained its initial strategy of doing the slow, steady, and often unrewarding work of changing legislation and articulating new laws. Working within the democratic arenas, through documents and routine process such as public parliamentary hearings, has granted SCN victories which are not easily celebrated: a forest that was not cut down, a powerplant that was not built, an oil field that was not developed (Asdal 2008, Reinertsen and Asdal 2010). Recently, the SCN succeeded with a similar strategy of working with the top-level-politicians to make the protection of rainforests a core component of Norwegian climate policies
(Hermansen, this issue). Again, the result of SCN's work may be considered an invisible victory: a political commitment to not cutting down trees, this time in sites across the globe. That said, it is a victory in the Norwegian political landscape, as the rainforest initiative has become the most important part of Norwegian climate mitigation policy, with broad support across the political spectrum.

Our reason for including this short narrative of key shifts and continuities of SCN's history is twofold: First, as an assertion of the empirical value and interest of the SCN as such and, in general, of historical STS (Asdal 2012). Second, little has been written of the SCN for an international audience. As we seek to show with the narrative above, SCN's history provides ample opportunities for analytical discussions that resonate with longstanding interests within and beyond the field of STS. SCN's long history contains the key contradictions of public engagement over nature, the environment, and climate change. Furthermore, its history attests to the at times complicated relations between academic expertise, lay activism, governmental initiatives, democratic processes, and nature objects. These features all make SCN a most interesting object of study within the context of both PES and STS research: How do publics engage with environmental issues? What different versions of engagement and democracy play out in the making and contesting of these very issues? How are institutional and temporal spaces of engagement crafted, and who crafts them? How do multiple scales of engagement - local, regional, national, global interact? What role does history and temporality play - how are specific pasts and futures established?

The work on SCN's history fed into the second part of the foundation for this special issue, in which the questions articulated above were of key concern: an informal discussion group on environmental NGOs meeting at TIK Centre for Technology, Innovation and Culture at the University of Oslo during the spring of 2013. Here, we united our separate empirical investigations of Norwegian ENGOs into a joint discussion of their characteristics. With reference to Yearley's empirically founded theory, we discussed our specific cases and saw how these challenged the conclusions from existing studies of the Norwegian environmental engagement (Bortne et al. 2002), which built upon by now 20 years old data from the 1995 Environmental Survey (Strømsnes et al. 1996, Strømsnes and Selle 1996). These findings in turn served as basis for international comparisons (Dryzek et al. 2003, Grendstad et al. 2006), whose conclusions about Norway diverged from what our own empirics suggested. This prompted us to consider how the study of Norwegian NGOs is in need of new empirical work, and furthermore, given Yearley's argument, that such an empirical expansion is also likely to also have analytical and theoretical implications (see also Swensen 2015). Our attempt at raising this issue resulted in a conference panel on the First Nordic STS Conference in Trondheim, April 2013, with papers by Erlend A.T. Hermansen, Ann-Sofie Kall, Sylvia Lysgård, Hilde Reinertsen, and Eirik Swensen. Hermansen's contribution has since been developed into the article presented in this special issue. 


\section{$\$$}

NORDIC JOURNAL

of Science and Technology Studies

Finally, the combination of analytical concerns and empirical curiosity informed the third part of the foundation for this special issue: the international workshop 'Engaging Environments: Analyzing publics and expertise on nature, the environment, and climate change', organized at the University of Oslo in May, 2013. Analytically, the workshop mobilized the broad questions posed at the outset of this introductory article, taking as its empirical point of departure the momentum of three major anniversaries: The twenty years' anniversary of the PUS journal in 2012; the centennial of the SCN in 2014; and the bicentennial of the Norwegian constitution, also in 2014. This combination of events lent itself to the opportunity of considering engagement, environment, and democracy in direct combination. This historical dimension enabled contrasts and continuities across time, while the workshop's international scope enabled us to see the Norwegian experience in a comparative perspective. The keynote contributions (Kristin Asdal, Alan Irwin, Sverker Sörlin, Brian Wynne, and Steven Yearley) brought this combination of sociological and historical concerns together. Alan Irwin's contribution in this issue is based on his opening discussion with Brian Wynne, in which they reflected upon the first 20 years of research on public engagement and the directions in which they would like to see the field move.

The present special issue consists of three articles that all engage with the core questions posed in this introduction. In combination, they unite detailed empirical investigations into past and present practices of public engagement with reflections on the theoretical scopes and ambitions of the fields of PES and STS at large.

Alan Irwin, in his article, raises fundamental concerns about the relationship between public engagement and democracy. Mobilizing empirical examples from Denmark and the UK, more specifically two consensus conferences on climate change adaptation and food security respectively, he investigates the modes of participation such exercises allow for. In discussing the potentials and limitations of engagement, Irwin asks: "Put simply, should such practical initiatives be seen as a distraction from the democratic process or instead as an enhancement or invigoration of it?" Noting that public engagement exercises are commonly concerned with local and national sites and issues, Irwin suggests the concept of 'decenteredness' as a way of transgressing national borders and including larger networks of global and non-governmental actors. In conclusion, he notes a certain disappointment over both the potential of public engagement and his own discussion and proceeds to articulate six principles of public engagement that may help address the democratic and governmental challenges of public engagement.

Whereas Alan Irwin's article reflects upon the phenomenon of public engagement at large, Erlend A.T. Hermansen brings out empirical details of one specific issue with which the Norwegian Society for the Conservation of Nature has engaged. In his article Hermansen investigates Norway's International Climate and Forest Initiative (NICFI), which was launched in 2007. Through a detailed analysis, Hermansen explains how the SCN together with the Norwegian Rainforest Foundation managed to make the classical concern for nature conservation a core part of the Norwegian climate policy. In discussing how they succeeded, Hermansen draws upon Yearley's characterization of ENGOs, notably their intimate relation to science, and argues that the two ENGOs managed to build support for a practical proposal that would enable Norway to cut carbon emissions abroad in a cost-efficient manner. In this way, Hermansen shows how public engagement and ENGO work must also be understood as providing specific political solutions.

Linda Soneryd pulls out key analytical points from the two above articles to further explore the role of public engagement in articulating and realizing alternatives to the status quo. Picking up on Irwin's notion that public engagement may play a key role in articulating alternatives, she argues for taking "a step back from the normative presupposition that public involvement will enhance environmental governance". Calling instead for an agnostic approach, Soneryd urges us instead to ask: "How are alliances created between issues and actors in relation to specific problems?" Using new empirical examples from an ongoing research project, Soneryd pays specific attention to the different scales of environmental governance and to how public engagement, and especially ENGOs, work across and between levels. In doing so, she explores how public engagement is indeed also practices of scaling and future-making.

The three articles all bring forth versions of public engagement with environment and democracy that go beyond the established conceptualization of environmental engagement as resistance: in combination, they demonstrate that engagement may involve participation, problem-solving, scaling, and future-making. In bringing these contributions together, we aim to enrich and expand already ongoing work within STS by both introducing new empirics and pushing the analytics. Furthermore, by bringing together internationally oriented scholars working out of Norway, Sweden, and Denmark, this special issue is a deliberate attempt at creating a Nordic context for the study of environmental engagement. Hopefully, this issue will inspire more studies of engaging environments in Nordic settings and beyond.

\section{Acknowledgements}

Many have contributed to realizing this special issue. We are most grateful to the article authors for their sustained engagement and good work; the editors of NJSTS for their interest and cooperation; a set of anonymous reviewers for their critical readings; professors Kristin Asdal and Göran Sundqvist for their ideas and comments throughout the process; colleagues Erlend A.T. Hermansen, Sylvia Lysgård, and Eirik Swensen for productive cooperation in preparing our joint panel on environmental NGOs during the First Nordic STS conference in April 2013; conference attendees for their useful comments during our session; TIK Center for Technology, Innovation and Culture at the University of Oslo for hosting the Engaging Environments workshop in May 2013 and for contributing 
funds to translate articles for this special issue; the interfaculty research area Kultrans (Cultural Transformations in the Age of Globalization) at the University of Oslo for workshop funding; Kultrans coordinator Beate Trandem for impeccable management of all workshop practicalities; workshop keynote speakers Kristin

\section{References}

Anshelm, J. 2004. Det vilda, det vackra och det ekologiskt hållbara. Om opinionsbildningen i Svenska Naturskyddsföreningens tidskrift Sveriges Natur 1943-2002. Umeå universitet.

Asdal, K. 2008. On Politics and the Little Tools of Democracy. A Down to Earth Approach. Distinktion. Scandinavian Journal of Social Theory 16: 5-26.

Asdal, K. 2011a. The Office: The Weakness of Numbers and the Production of Non-Authority. Accounting, Organizations and Society 36(1): 1-9.

Asdal, K. 2011b. Politikkens natur - naturens politikk. Universitetsforlaget.

Asdal, K. 2012. Contexts in Action-And the Future of the Past in STS. Science, Technology \& Human Values 37 (4): 379-403.

Berntsen, B. 2014. Grønne linjer. Natur- og miljøvernets historie i Norge. 3. ed. Universitetsforlaget.

Bortne, Ø., P. Selle and K. Strømsnes. 2002. Miljøvern uten grenser? Gyldendal Akademisk.

Dryzek, J. S., D. Downes et al. 2003. Green states and social movements: Environmentalism in the United States, United Kingdom, Germany and Norway. Oxford University Press.

Grendstad, G., P. Selle et al. 2006. Unique Environmentalism - a Comparative Perspective. Springer.

Gundersen, F. 1991. Utviklingstrekk ved miljøbevegelsen i Norge. Sosiologi i dag 2: 12-35.

Irwin, A. 1995. Citizen Science. A Study of People, Expertise and Sustainable Development. Routledge.

Irwin, A. 2001. Sociology and the Environment. A Critical Introduction to Society, Nature and Knowledge. Polity Press.

Latour, B. 2004. Why Has Critique Run out of Steam? From Matters of Fact to Matters of Concern. Critical Inquiry 30: 225-248.

Leach, M., I. Scoones and B. Wynne (eds.) 2005. Science and Citizens. Globalization and the challenge of engagement. Zed Books.
Asdal, Alan Irwin, Sverker Sörlin, Bryan Wynne and Steven Yearley and commentators Linda Soneryd, Göran Sundqvist and Karen Lykke Syse for their contributions; and workshop participants for enabling a most engaging discussion environment.

Lidskog, R. and G. Sundqvist. 2011. Miljösociologi. Studentlitteratur AB.

Marres, N. 2007. The Issues Deserve More Credit. Pragmatist Contributions to the Study of Public Involvement in Controversy. Social Studies of Science 37(5): 759-780.

Naturskyddsföreningen 2009. Hundra år av envishet. Naturskyddsföreningens temabok, Naturskyddsföreningen.

Nilsen, Y. 2008. Ideologi eller kompleksitet? Motstand mot vannkraftutbygging i Norge i 1970-årene. Historisk Tidsskrift 138 (1): 61-84.

Olsen, S. 2015. Kampen om Danmarks natur. Fra fredskovsforordningen til genskabelsen av Filsø. Gads forlag.

Reinertsen, H. and K. Asdal. 2010. Fra naturfredning til klimakamp: Norges Naturvernforbund 1914-2014. TIK publication series, vol 1. Unipub.

Soneryd, L. and S. Weldon. 2003. Noise and newts: public engagement in the UK and Sweden. Environmental Impact Assessment Review 23(1): 17-37.

Strømsnes, K., G. Grendstad and P. Selle. 1996. Miljøundersøkelsen 1995. Dokumentasjonsrapport. Rapport 9616, LOS-senteret.

Strømsnes, K. and P. Selle (eds.) 1996. Miljøvernpolitikk og miljøvernorganisering mot år 2000. Tano Aschehoug.

Swensen, E. F. 2015. Mellom klimanødvendighet og teknologisk tvil - miljøbevegelsens rolle i karbonfangst og -lagring (CCS). Sosiologi i dag 45(1): 53-73.

Trædal, E. 2013. Old dogs, new tricks. An exploration of local climate activism in Norway and Denmark. Master thesis, SUM Center for Development and the Environment, University of Oslo.

Wynne, B. 1992. Misunderstood misunderstanding: social identities and public uptake of science. Public Understanding of Science 1(3): 281-304.

Yearley, S. 2005. Cultures of Environmentalism. Empirical Studies in Environmental Sociology. Basingstoke: Palgrave Macmillian. 